\title{
ECOPHYSIOLOGICAL ANALYSIS OF Eucalyptus camaldulensis (DEHNH) SUBMITTED TO ATTACK FROM Thaumastocoris peregrinus (CARPINTERO \& DELLAPE) ${ }^{1}$
}

Kamilla Emmanuelle Carvalho de Almeida ${ }^{2 *}$, Junia Grazielle Soares da Silva ${ }^{3}$, Inaê Mariê de Araujo Silva ${ }^{4}$, Alisson Lucrecio da Costa ${ }^{5}$ and Marcelo Luiz de Laia ${ }^{6}$

\footnotetext{
${ }^{1}$ Received on 31.05.2017 accepted for publication on 05.01.2018.

${ }^{2}$ Universidade Federal dos Vales do Jequitinhonha e Mucuri, Programa de Pós-Graduação em Ciência Florestal, Diamantina, MG- Brasil. E-mail: <carvalho.kmll@gmail.com>.

${ }^{3}$ Universidade Federal dos Vales do Jequitinhonha e Mucuri, Programa de Pós-Graduação em Engenharia Florestal, Diamantina, MG - Brasil. E-mail: <juniagss@msn.com>.

${ }^{4}$ Universidade de Brasília, Doutora em Ciência Florestal, DF- Brasil. E-mail: <inaemarie@hotmail.com>.

${ }^{5}$ Instituto Federal Goiano - Câmpus Iporá, Iporá, GO - Brasil. E-mail: <alissonluc@gmail.com>.

${ }^{6}$ Universidade Federal dos Vales do Jequitinhonha e Mucuri, Departamento de Engenharia Florestal, Diamantina, MG- Brasil. E-mail: <marcelolaia@gmail.com>.

*Corresponding author.
}

\begin{abstract}
Works correlating the effect of a bronze bug attack on ecophysiological aspects of eucalyptus can be used in selection programs for resistant genetic materials. The objective of this study was to evaluate the injuries caused by Thaumastocoris peregrinus (Carpintero \& Dellape) through the ecophysiological analysis of Eucalyptus camaldulensis (Dehnh). The experiment was conducted in a completely randomized design, with two groups of plants, infested and non-infested, kept in a room at $25 \pm 2{ }^{\circ} \mathrm{C}$, relative humidity $60 \pm$ $2 \%$ and a photoperiod of 12 hours. For 26 days, every 48 hours, the chlorophyll $a$ fluorescence, using the electron transport rate $(E T R)$ and the potential quantum efficiency $(F v / F m)$, was measured, in addition to the leaf chlorophyll content of the plants. The variables observed were analyzed in relation to treatments and times using a mixed linear model, with plants and leaves being random effects. Plants protected from insect attack showed better results over the experimental period. However, the attack from the bronze bug negatively affected all the ecophysiological variables evaluated in E. camaldulensis, indicating a possible compromise of the photosynthetic apparatus of the plants.
\end{abstract}

Keywords: Eucalyptus; Bronze bug; Ecophysiology.

\section{ANALISE ECOFISIOLÓGICA DE EUCALYPTUS CAMALDULENSIS (DEHNH) SUBMETIDOS AO ATAQUE DE THAUMASTOCORIS PEREGRINUS (CARPINTERO \& DELLAPE)}

\begin{abstract}
RESUMO - Trabalhos que relacionem o efeito do ataque do percevejo bronzeado sobre aspectos ecofisiológicos do eucalipto podem ser empregados em programas de seleção de materiais genéticos resistentes. O objetivo deste trabalho foi avaliar as injúrias provocadas por Thaumastocoris peregrinus (Carpintero \& Dellape) através da análise ecofisiológica de Eucalyptus camaldulensis (Dehnh). O experimento foi conduzido em um delineamento inteiramente casualizado, com dois grupos de plantas, infestadas e não infestadas, mantidas em sala climatizada a $25 \pm 2{ }^{\circ} \mathrm{C}$, umidade relativa $60 \pm 2 \%$ e fotoperiodo de 12 horas. Durante 26 dias, a cada 48 horas, foram avaliadas a fluorescência da clorofila a, a partir dos dados de transferência de elétrons (ETR) e a eficiência quântica potencial ( $\mathrm{Fv} / \mathrm{Fm})$, além do teor de clorofila foliar das plantas. As variáveis observadas foram analisadas em relação aos tratamentos e aos tempos usando modelo linear misto, com planta e folha como um efeito aleatório. Plantas protegidas do ataque do inseto apresentaram melhores resultados ao longo do período experimental. Entretanto, o ataque do percevejo bronzeado afetou negativamente todas as variáveis ecofisiológicas avaliadas em E. camaldulensis, indicando um possivel comprometimento do aparato fotossintético das plantas.
\end{abstract}

Palavras-Chave: Eucalipto; Percevejo bronzeado; Ecofisiologia.

Revista Árvore. 2018;42(1):e420120 


\section{INTRODUCTION}

Thaumastocoris peregrinus (Carpintero \& Dellapé) is an insect of Australian origin rapidly spreading across various countries. Monitoring its presence, as well as its effects on eucalyptus plantations, is fundamental for efficient management of the forest system, resulting in stable production. The feeding habit of the bronze bug causes silvering (chlorosis) of the leaves, which gradually turn to brown and red, giving the forest canopy a bronze appearance, followed by the leaves drying and falling, giving rise to a reduction in the photosynthetic area of the plant, possibly causing trees to die in cases of severe infestation (Jacobs and Neser, 2005; Button, 2007; Wilcken et al., 2010).

Leaves subjected to stressors of biotic or abiotic origin, including herbivorous insects, are subject to different types of injuries, where the extension and severity of the damages may vary (Stone et al., 2001). The progressive loss of photosynthetic tissues, and/ or the reduction of leaf area because of the insects, causes a decrease in photosynthetic capacity, reducing the production of biomass and plant performance (Edwards and Wratten, 1981; Sagers and Coley, 1995). Photosynthetic pigments are related to environmental stresses (Carter and Knapp, 2001; Spitale, 2006; Xue et al., 2011) and are commonly associated with processes that involve the degradation of chlorophylls and decrease in photosynthetic capacity (Marenco and Lopes, 2005; Hatfield et al., 2008). The occurrence of chlorosis in leaves is also associated with the feeding habit of sapsucking insects and this is an important parameter to be considered in the studies on interactions between plants and herbivorous insects (Ni et al., 2001).

In this sense, the herbivorous action of insects triggers a complex interactive set of molecular and physiological responses in plants according to the type of damage caused by the insects feeding and the defense mechanisms developed by the plants, when suffering an attack from the insect (Nabity et al., 2009). Ecophysiological studies help make sense of the different ways plants respond to environmental variations, as well as their capacity to adapt to different stress conditions, including the presence of insects (Bown et al., 2002).

The measurements of the leaf chlorophyll content and the chlorophyll $a$ fluorescence are key tools, frequently used for investigating the response of plants to lesions caused by the feeding habit of those insects (Iatrou et al., 1995; Burd and Elliott, 1996; Bounfour et al., 2002). From among the different parameters of chlorophyll fluorescence that can be assessed, the quantum yield of photosystem II (PSII) $(f v / f m)$ was used to compare healthy tissues to those with damages caused by biotic factors. Significant decreases in this variable indicate that, possibly, the PSII reaction centers were damaged. Another variable frequently observed is the electron transport rate (ETR). For successful photosynthesis, the electron transport chain must function satisfactorily, guaranteeing the production of ATP (Adenosine Triphosphate) and NADPH (Nicotinamide Adenine Dinucleotide Phosphate) necessary for the continuation of the photosynthetic process (Chaves, 2015).

This work aimed at verifying the influence of the T. peregrinus attack on the photosynthetic performance of the E. camaldulensis leaves over time, by means of ecophysiological analyses.

\section{MATERIALAND METHODS}

The experiment was carried out in a climatized room ( $25 \pm 2{ }^{\circ} \mathrm{C}$, HR $60 \pm 2 \%$ and photoperiod of 12 hours), at CIPEF (Centro Integrado de Propagação de Espécies Florestais [Integrated Center for the Propagation of Forest Species]), located in the Departamento de Engenharia Florestal (Department of Forest Engineering), JK Campus, of the Universidade Federal dos Vales do Jequitinhonha e Mucuri (Federal University of the Valleys of Jequitinhonha and Mucuri), in Diamantina, state of Minas Gerais.

Eucalyptus camaldulensis (Dehnh) seedlings produced in plastic tubettes were transplanted into 7 liter buckets containing substrate collected from 5 $\mathrm{cm}$ below the superficial soil layer and kept under direct sunlight. The plants were irrigated daily and received mineral nutrition by application of ammonium sulfate, potassium chloride, limestone, osmocot and simple superphosphate to the substrate. Coverage fertilizations with urea and ammonium sulfate dissolved in water were performed every 20 days. The ecophysiological study started 120 days after the transplantation of the plants into vases, and then placed in the acclimatized room and kept under a $100 \mathrm{ìmol} \mathrm{m}^{-2} \mathrm{~s}^{-1}$ flow of active photosynthetic photons. After seven days of acclimatization, adult insects collected from a commercial plantation were transferred to the plants, simulating

Revista Árvore. 2018;42(1):e420120

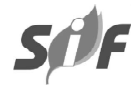


a natural insect attack. It must be emphasized that due to the behavioral habits of the insect, attempts to confine insects for experimental purposes showed to be ineffective. Hence, to guarantee high density and standardization of bugs on the plants daily transfers of insects were done during the whole experimental period. Another group of plants was kept in protected cages, avoiding contact with insects. These plants represented the control group.

For 26 days, every 48 hours, the relative content of total chlorophyll quantified by means of a Soil Plant Analysis Development (SPAD-502, Minolta, Japan) chlorophylometer at two points on each side of the central nerve of the leaves and the chlorophyll $a$ fluorescence variables were measured at the surface of the expanded previously selected leaves, located on the middle third of the seedling with a significant presence of insects determined using a portable PAM fluorometer (JUNIOR-PAM, Heinz Walz GmbH). The initial fluorescence $(F o)$, maximum fluorescence $(F m)$ and the variable fluorescence $(F v)$ were measured to determine the potential quantum efficiency of PSII $(F v /$ $F m=(F m-F o) / F m)$ and the electron transport rate (ETR). The measurements were taken between 7 p.m. and 9 p.m., after a 30 min pre-adaptation of the leaves to the dark.

The experiment was conducted in a Fully Randomized Design (FRD), with two groups of plants: infested and non-infested. There were 20 experimental units (plants), where each plant had two of its leaves assessed. There were 13 evaluations carried out, always employing the same leaves, the first evaluation being carried out before the seedlings received insects. The same evaluations were also carried out on the leaves of the plants that represent the control group. The parameters for chlorophyll fluorescence $(F v / F m$ and $E T R)$ and chlorophyll content were analyzed in relation to the treatments and times using a mixed linear model, with plants and leaves being random effects. The statistic analyses were conducted in environment R 3.0.1 ( $R$ Core Team, 2014), using lme4, arm and lmerTest packages.

\section{RESULTS}

The result of the analysis of variance using the mixed linear model approach showed a significant difference between the sets of plants protected and unprotected against bronze bug attacks (Table 1).

The values registered for the relative content of the leaf chlorophyll in the set of plants infested with the bug were higher at the start of the experiment than those measured in the protected plant set, possibly due to the use of cages to confine them. The plants kept outside the cages during the acclimatization period probably made better use of the abiotic factors before being subjected to the bug attack when compared to the plants kept inside cages. However, in the first days of the experimental period it was possible to detect a decrease in the values observed for this variable in the leaves of infested plants, when compared to leaves of protected plants, which displayed little variation

Table 1 - Analysis of variance of the mixed linear model with p-value for the fixed effects according to the F-test based on the Satterthwaite approximation and p-value for the random effects based on the log-likelihood ratio for leaf chlorophyll content, electron transport rate (ETR) and quantum efficiency of photosystem II (Fv/Fm).

Tabela 1 - Análise de variância do modelo linear misto com p-valor para os efeitos fixos de acordo com teste de $F$ baseado na aproximação de Satterthwaite e p-valor para os efeitos aleatórios baseado na razão de log-verossimilhança para teor de clorofila foliar, taxa de transporte de elétrons (ETR) e eficiência quântica do fotossistema II (Fv/ Fm).

\begin{tabular}{|c|c|c|c|c|c|c|c|c|c|}
\hline \multicolumn{4}{|c|}{ Leaf chlorophyll content } & \multicolumn{3}{|c|}{ ETR } & \multicolumn{3}{|c|}{$F v / F m$} \\
\hline \multirow{3}{*}{$\begin{array}{l}\text { Fixed effects } \\
\text { Parameter }\end{array}$} & & & & & & & & & \\
\hline & DF & $\mathrm{Sq}$ & p-value & $\mathrm{DF}$ & $\mathrm{Sq}$ & p-value & DF & $\mathrm{Sq}$ & p-value \\
\hline & 1 & 944.29 & $<.0001 * * *$ & 1 & 1023.20 & $<.0001 * * *$ & 1 & 0.71 & $<.0001 * * *$ \\
\hline Condition Time & 2 & 4271.8 & $<.0001 * * *$ & 2 & 18323.13 & $<.0001 * * *$ & 2 & 6.92 & $<.0001 * * *$ \\
\hline Random effects & & & & & & & & & \\
\hline Parameter & Chi DF & Chi Sq & p-value & Chi DF & Chi Sq & $\mathrm{p}$-value & Chi DF & Chi Sq & p-value \\
\hline Plant: Leaf & 1 & 228.06 & $<.0001 * * *$ & 1 & 0 & 0 n.s. & 1 & 30.69 & $<.0001 * * *$ \\
\hline $\mathrm{R}^{2}$ marginal* & & 0.4450 & & & 0.7020 & & & 0.6387 & \\
\hline $\mathrm{R}^{2}$ conditional* & & 0.8323 & & & 0.7020 & & & 0.6890 & \\
\hline
\end{tabular}




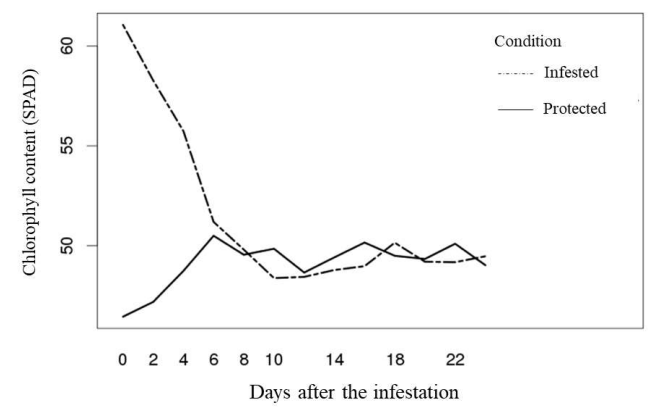

Figure 1 - Mean values of relative chlorophyll content of Eucalyptus camaldulensis plants, under two conditions of infestation (infested and non-infested) by Thaumastocoris peregrinus at different times of evaluation.

Figura 1 - Valores médios de teor relativo de clorofila de plantas de Eucalyptus camaldulensis, sob duas condições de infestação (infestadas e não infestadas) por Thaumastocoris peregrinus, em diferentes tempos de avaliação.

throughout the experiment (Figure 1). These results indicate that bug attack on eucalyptus plants may affect leaf chlorophyll content levels detectable by SPAD. It is important to take into consideration the fact that

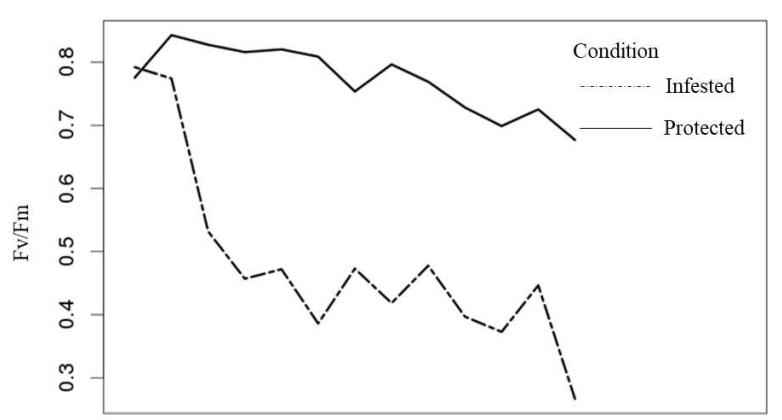

$\begin{array}{lllllllll}0 & 2 & 4 & 6 & 8 & 10 & 14 & 18 & 22\end{array}$

Days after the infestation

Figure 2 - Mean values of the quantum efficiency ( $\mathrm{Fv} / \mathrm{Fm})$ of Eucalyptus camaldulensis plants, under two conditions of infestation (infested and non-infested) by Thaumastocoris peregrinus at different times of evaluation.

Figura 2-Valores médios de eficiência quântica do Fotossistema II (Fv/Fm) de plantas de Eucalyptus camaldulensis, sob duas condições de infestação (infestadas e não infestadas) por Thaumastocoris peregrinus, em diferentes tempos de avaliação.

Revista Árvore. 2018;42(1):e420120

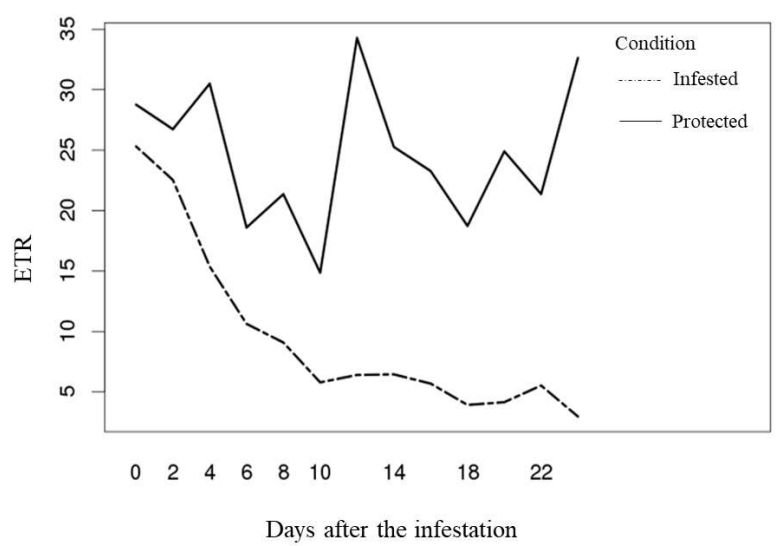

Figure 3 - Mean values of Electron Transport Rate (ETR) of Eucalyptus camaldulensis plants, under two conditions of infestation (infested and non-infested) by Thaumastocoris peregrinus, at different times of evaluation.

Figura 3 - Valores médios de Taxa de Transporte de Elétrons (ETR) de plantas de Eucalyptus camaldulensis, sob duas condições de infestação (infestadas e não infestadas) por Thaumastocoris peregrinus, em diferentes tempos de avaliação.

there was little discrepancy in the differences between treatments over the course of the days, making it necessary to expand the study, taking aspects such as intensity of the attack and time period of the infestation into account.

In relation to $F v / F m$, the results suggested there was significant difference between the values registered for the set of plants infested by and protected from insect attack throughout the experimental period. Adecrease in this variable was observed in both infested plants and protected plants. However, the reduction observed for this variable in protected plants was less than that observed in infested plants (Figure 2). This reduction could well be a characteristic of the species, but the insect attack possibly accelerated this process.

Apart from the reduction in the photochemical efficiency of PSII, the bronze bug attack also provoked major drops in the values of ETR in infested plants, when compared with values registered for plants protected from insect attacks during the experimental period (Figure 3 ).

\section{DISCUSSION}

In this work, it was demonstrated that the presence of bronze bugs was mainly responsible for the reduction 
of two important parameters, potential quantum efficiency of PSII (FV/Fm) and the electron transport rate (ETR) in the efficiency of the photosynthetic apparatus of E. camaldulensis and leaf chlorophyll content, which is compatible with other studies.

On assessing the relative content of chlorophyll of tomato leaves in response to the attack of Phenacoccus solenopsis (Hemiptera: Pseudococcidae) Huang et al. (2013) registered significant decreases in this variable in plants subjected to a high level of infestation. Similarly, infestations by Diuraphis noxia (Hemiptera: Aphididae) caused significant reductions in the leaf chlorophyll content of wheat and barley plants susceptible to attacks from this insect (Burd and Elliott, 1996). Go ${ }^{3}$ awska et al. (2011) also registered decreases in chlorophyll content in fabaceae subjected to a severe level of infestation by Acyrthosiphon pisum (Hemiptera: Aphididae) and suggested that the decrease in concentration of this pigment could be associated with the increase in production of the defense compounds, in response to herbivory.

The mechanism through which the herbivory, provoked by the eucalyptus bronze bug, can affect the metabolism of the plants is still not exactly known. Meanwhile, the chlorosis symptoms, observed in the eucalyptus leaves, indicated that the sucking feeding habit of $T$. peregrinus may have affected the chlorophyll, causing progressive photosynthetic capacity loss. This can be confirmed by the leaf chlorophyll content of the plants in the first days of insect attack, behavior opposite to that observed in the protected plants that, although they presented lower values for this variable, they maintained constant performance during the whole of the experimental period.

Analysis of the chlorophyll $a$ fluorescence is used in the monitoring of the processes related to the photosynthetic physiology of the plants (Bounfour et al., 2002; Retuerto et al., 2004). Apart from this, the analysis can be employed as an indicator of plant response to the different stressors, including injuries caused by insects (Haile et al., 1999).

The ratio $F v / F m$ has been used as a diagnostic tool to detect different physiological stresses that cause a decline in the values observed for this variable, a phenomenon known as photoinhibition (Krause \& Weis, 1991). Normally, plants with their photosynthetic apparatus in a perfect state and ideal conditions of development display $F v / F m$ values varying between 0.75 and 0.85 . $F v / F m$ values below 0.75 may indicate alterations in the photosynthetic apparatus of the plants and impairment in the efficiency of the use of luminous energy by PSII (Bolhàr-Nordenkampf et al., 1989). The effect of injury caused by bronze bugs on plants can be verified in the $F v / F m$ ratio, which suffered expressive reductions over time. At the end of the experiment, the insect infested plants displayed values inferior to 0.30 , a sign of photoprotective regulation or irreversible inactivation of PSII.

The decrease in the $F v / F m$ ratio in eucalyptus plants infested with $T$. peregrinus coincides with behavior observed by Velikova et al. (2010) on registering a significant reduction in $F v / F m$ values of herbaceous plants subjected to a high infestation of bugs of the species Murgantia histrionica (Hemiptera: Pentatomidae) and Nezara viridula (Hemiptera: Pentatomidae). Similar results were observed by Blanco et al. (1992) on comparing changes in $F v / F m$ values of two variables of alfalfa due to attack from aphids Therioaphis trifolii (Hemiptera: Aphididae) and Acyrthosiphon pisum (Hemiptera: Aphididae). Reductions in the $F v / F m$ parameters were also observed in tobacco leaves attacked by Bemisia tabaci (Hemiptera Aleyrodidae) (Li et al., 2013) and lemon attacked by Coccus hesperidum (Hemiptera: Coccidae) (Golan et al., 2015), in response to biotic stress.

For the electron transport rate (ETR), differences were also observed between values registered for the set of plants protected from and infested by T. peregrinus, where, the bronze bug attack caused decreases in ETR values in infested plants. The variable ETR provides an estimate of the proportion of photons absorbed that are used for the photochemical condition in PSII and this is expressed as one of the parameters of fluorescence. The results suggest the presence of insects on the leaves may have disturbed the synthesis of the fluorescence, by the destruction of photosynthetic organs, and possibly, the transference of electrons in these plants is not taking place efficiently. In this situation the high quantity of chlorophylls excited gives rise to oxidative processes in PSII of the plant, tending to dissipate energy generated by absorption of light in another manner, rather than through its use of photosynthesis (Chaves, 2015).

Analogous results were found by Huang et al. (2013) on examining the effect of different intensities 
of infestation by Phenacoccus solenopsis (Tinsley) on parameters related to chlorophyll fluorescence in tomato plants, registering significant decline in the values of ETR in plants subjected to a high rate of infestation. In their works, Welter (1989) and Zangerl et al. (2002) also report instances of loss in the quantum yield and electron transport rate of plants attacked by folivores.

Damages caused by insect attacks are frequently associated to complex processes that can affect gas exchange in the remaining leaf tissue and alter the photochemical status of the plant (Aldea et al., 2005). In the case of sucking insects, the photosynthetic capacity of the plants can be reduced, according to the type of injury generally associated with the removal of vegetable tissues and the interruption of normal physiological plant processes (Haile, 2001).

Defense responses of the plants to insect attacks are very often related to reductions in the photosynthetic rate (Bilgin et al., 2010). Genotypes capable of maintaining the photosynthetic rate under these conditions, possibly display a greater tolerance, that is, the capacity of the plant to satisfactorily grow, develop and produce, even under certain levels of infestation by herbivores (Kerchev et al., 2012). Hence, by kinetic analysis of the emission of chlorophyll fluorescence it is possible to diagnose the level of stress in the plants provoked by the insect, according to its feeding habit. Kinetic analysis is the appropriate technique for studying systemic effects of plant pathogens, as well as tracking genotypes resistant to the attack of insects, contributing to the development of basic and applied research on the tolerance of plants (Blanco et al., 1992).

\section{CONCLUSIONS}

Bronze bug attacks affect the photosynthetic capacity of Eucalyptus camaldulensis leaves, reducing, in particular, the parameters of chlorophyll $a$ fluorescence (ETR and $\mathrm{Fv}_{\mathrm{V}} / \mathrm{Fm}$ ).

The analysis of the ecophysiological variables can be employed in new studies that seek to differentiate eucalyptus genotypes resistant and susceptible to the bronze bug.

\section{ACKNOWLEDGMENTS}

Our thanks go to Embrapa Florestas, Embrapa Milho e Sorgo, APERAM Bioenergia and GERDAU S/A, the
Federal University of the Valleys of Jequitinhonha and Mucuri, FAPEMIG (Fundação de Amparo à Pesquisa de Minas Gerais [Minas Gerais Research Funding Foundation]) and to CAPES (Conselho de Aperfeiçoamento de Pessoal de Nível Superior [Coordination for the Improvement of Higher Education Personnel]) for their partnership and help in the development of this research.

\section{REFERENCES}

Aldea M, Hamilton JG, Resti JP, Zangerl AR, Berenbaum MR, Delucia EH. Indirect effects of insect herbivory on leaf gas exchange in soybean. Plant Cell Environ. 2005 jan;28(5):402-11. http:// dx.doi.org/10.1111/j.1365-3040.2005.01279.x.

Bilgin DD, Zavala JA, Zhu J, Clough SJ, Ort DR, DeLucia EH. Biotic stress globally downregulates photosynthesis genes. Plant Cell Environ. 2010 out;33(10):1597-613. http://dx.doi.org/10.1111/ j.1365-3040.2010.02167.x. PMid:20444224.

Blanco LR, Adamson HY, Hales DF. Chlorophyll fluorescence kinetics as a measure of stress in plants infested with aphids: implications for studies of resistance. Austral Entomol. 1992 jul;31(3):222. http://dx.doi.org/10.1111/j.14406055.1992.tb00491.x.

Bolhàr-Nordenkampf HR, Long SP, Baker NR, Oquist G, Schreiber U, Lechner EG. Chlorophyll fluorescence as probe of the photosynthetic competence of leaves in the field: a review of current instrument. Funct Ecol. 1989 jan;3(4):497514. http://dx.doi.org/10.2307/2389624.

Bounfour M, Tanigoshi LK, Chen C, Cameron SJ, Klauer S. Chlorophyll content and chlorophyll fluorescence in red raspberry leaves infested with Tetranychus urticae and Eotetranychus carpini borealis (Acari: Tetranychidae). Environ Entomol. 2002 abr;31(2):215-20. http://dx.doi.org/10.1603/ 0046-225X-31.2.215.

Bown AW, Hall DE, Macgregor KB. Insect footsteps on leaves stimulate the accumulation of 4-aminobutyrate and can be visualized through increased chlorophyll fluorescence and superoxide production. Plant Physiol. 2002 ago;129(4):1430-4. http://dx.doi.org/10.1104/pp.006114.

PMid:12177456.

Revista Árvore. 2018;42(1):e420120 
Burd JD, Elliott NC. Changes in chlorophyll a fluorescence induction kinetics in cereals infested with Russian wheat aphid (Homoptera:

Aphididae). J Econ Entomol. 1996 out;89(5):13327. http://dx.doi.org/10.1093/jee/89.5.1332.

Button G. Thaumastocoris peregrinus. Forestry facts. South Africa: NCT Forestry; 2007 [cited $2013 \mathrm{Jul}$ 1]. Available from: http:// www.nctforest.com/ showpage. asp id $=44 \&$ contentid $=423 \&$ catid $=24$

Carter GA, Knapp AK. Leaf optical properties in higher plants: linking spectral characteristics to stress and chlorophyll concentration. Am J Bot. 2001 abr;88(4):677-84. http://dx.doi.org/10.2307/ 2657068. PMid:11302854.

Chaves VV. Trocas gasosas e fluorescência da clorofila "a" em genótipos de cana-de-açúcar infestados por cigarrinha-das-raízes Mahanarva fimbriolata [dissertação]. Viçosa: Universidade Federal de Viçosa; 2015.

Edwards PJ, Wratten SD. Ecologia das interações entre insetos e plantas. Tradução Vera Lúcia Imperatriz Fonseca. São Paulo: EDUSP; 1981.

Golan K, Rubinowska K, Kmieæ K, Kot I, GórskaDrabik E, £agowska B, et al. Impact of scale insect infestation on the content of photosynthetic pigments and chlorophyll fluorescence in two host plant species. Arthropod-Plant Interact. 2015 fev;9(1):55-65. http://dx.doi.org/10.1007/s1 1829-014-9339-7.

Goªwska S, Krzy¿anowski R, £ukasik I. Relationship between aphid infestation and chlorophyll content in fabaceae species. Acta Biol Cracov Ser. Bot. 2011 fev;52(2):76-80.

Haile FJ. The influence of cultivar and plant architecture on yield loss. In: Peterson RKD, Higley LG, editores. Biotic stress and yield loss. Boca Raton: CRC Press; 2001.p. 99-116.

Haile FJ, Higley LG, Ni X, Quisenberry SS. Physiological and growth tolerance in wheat to Russian wheat aphid (Homoptera: Aphididae) injury. Environ Entomol. 1999 out;28(5):787-94. http://dx.doi.org/10.1093/ee/28.5.787.

Hatfield JL, Gitelson AA, Schepers JS, Walthall
CL. Application of spectral remote sensing for agronomic decisions. Agron J. 2008 jan;100(3):117-31.

Huang J, Zhang PJ, Zhang J, Lu YB, Huang F, Li MJ. Chlorophyll content and chlorophyll fluorescence in tomato leaves infested with an invasive mealybug, Phenacoccus solenopsis (Hemiptera: Pseudococcidae). Environ Entomol. 2013 out;42(5):973-9. http://dx.doi.org/10.1603/ EN12342. PMid:24073741.

Iatrou G, Cook CM, Stamou G, Lanaras T. Chlorophyll fluorescence and leaf chlorophyll content of bean leaves injured by spider mites (Acari: Tetranychidae). Exp Appl Acarol. 1995 out;19(10):581-91. http://dx.doi.org/10.1007/ BF00048813.

Jacobs DH, Neser S. Thaumastocoris australicus Kirkaldy (Heteroptera: Thaumastocoridae): a new insect arrival in South Africa, damaging to Eucalyptus trees: research in action. S Afr J Sci. 2005 maio;101(5):233-6.

Kerchev PI, Fenton B, Foyer CH, Hancock RD. Plant responses to insect herbivory: interactions between photosynthesis, reactive oxygen species and hormonal signalling pathway. Plant Cell Environ. 2012 jun;35(2):441-53. http://dx.doi.org/ 10.1111/j.1365-3040.2011.02399.x. PMid:21752032.

Krause H, Weis E. Chlorophyll fluorescence and photosynthesis: the basics. Annu Rev Plant Physiol Plant Mol Biol. 1991 jun;42(1):313-49. http://dx.doi.org/10.1146/ annurev.pp.42.060191.001525.

Li Q, Tan W, Xue M, Zhao H, Wang C. Dynamic changes in photosynthesis and chlorophyll fluorescence in Nicotiana tabacum infested by Bemisia tabaci (Middle East-Asia Minor 1) nymphs. Arthropod-Plant Interact. 2013 ago;7(4):431-43. http://dx.doi.org/10.1007/s11829013-9260-5.

Marenco RA, Lopes NF. Fisiologia vegetal: fotossíntese, respiração, relações hídricas e nutrição mineral. Viçosa: UFV; 2005. 451 p.

Nabity PD, Zavala JA, zaaia EH. Indirect suppression of photosynthesis on individual leaves by arthropod herbivory. Ann Bot. 2009 
fev;103(4):655-63. http://dx.doi.org/10.1093/aob/ mcn127. PMid:18660492.

Ni X, Quisenberry SS, Markwell J, Heng-Moss T, Higley L, Baxendale F, et al. In vitro enzymatic chlorophyll catabolism in wheat elicited by cereal aphid feeding. Entomol Exp Appl. 2001 set;101(2):159-66. http://dx.doi.org/10.1046/j.15707458.2001.00900.x.

R Core Team. R: a language and environment for statistical computing. Vienna: R Foundation for Statistical Computing; 2014 [cited 2014 Jul 16]. Available from: http://www.R-project.org/

Retuerto R, Fernandez-Lema B, Rodriguez-Roiloa, Obeso JR. Increased photosynthetic performance in holly trees infested by scale insects. Funct Ecol. 2004 set;18(5):664-9. http://dx.doi.org/ 10.1111/j.0269-8463.2004.00889.x.

Sagers CL, Coley PD. Benefits and costs of plant defense in a neotropical shrub. Ecology. 1995 set;76(6):1835-43. http://dx.doi.org/10.2307/ 1940715 .

Spitale D. Spatial distribution of bryophytes along a moisture gradient: an approach using photosynthetic pigments as indicators of stress. Ecol Res. 2006 nov;24(6):1279-86. http:// dx.doi.org/10.1007/s11284-009-0614-5.

Stone C, Chisholm L, Coops N. Spectral reflectance characteristics of eucalypt foliage damaged by insects. Aust J Bot. 2001 dez;49(6):687-98. http://dx.doi.org/10.1071/ BT00091.

Velikova V, Salerno G, Frati F, Peri E, Conti E, Colazza $S$, et al. Influence of feeding and oviposition by phytophagous pentatomids on photosynthesis of herbaceous plants. J Chem Ecol. 2010 maio;36(6):629-41. http://dx.doi.org/ 10.1007/s10886-010-9801-7. PMid:20490900.

Welter SC. Arthropod impact on plant gas exchange. In: Bernays EA, editor. Insect-plant interactions. Boca Raton: CRC; 1989. p. 135-150.

Wilcken C, Soliman E, Sá L, Barbosa L, Ribeiro Dias T, Ferreira-Filho P, et al. Bronze bug Thaumastocoris peregrinus Carpintero \& Dellapé (Hemiptera: Thaumastocoridae) on Eucalyptus in Brazil and its distribution. Journal Research of Plant Protection. 2010 jun;50(2):184-8. http:// dx.doi.org/10.2478/v10045-010-0034-0.

Xue LL, Anjum SA, Wang LC, Saleem MF, Liu XJ, Ijaz MF, et al. Influence of straw mulch on yield, chlorophyll contents, lipid peroxidation and antioxidant enzymes activities of soybean under drought stress. J Food Agric Environ. 2011 abr;9(2):699-704.

Zangerl AR, Hamilton JG, Miller TJ, Crofts AR, Oxborough $\mathrm{K}$, Berenbaum MR, et al. Impact of folivory on photosynthesis is greater than the sum of its holes. Proc Natl Acad Sci USA. 2002 jan;99(2):1088-91. http://dx.doi.org/10.1073/ pnas.022647099. PMid:11792866. 